\title{
Pengaruh Ukuran dan Fraksi Organik Terhadap Kuantitas dan Kualitas Timbulan Lindi
}

\author{
Kasam $^{1)}{\text { : } \text { Sarto }^{2)} \text {; Siti Syamsiah }}^{2)}$ dan Agus Prasetyo ${ }^{2)}$ \\ 1) Jurusan Teknik Lingkungan, Fakultas Teknik Sipil dan Perencanaan, Universitas Islam Indonesia; \\ 2) Jurusan Teknik Kimia, Fakultas Teknik, Universitas Gadjah Mada
}

\begin{abstract}
Abstrak
Timbunan sampah pada landfill (TPA) akan mengalami degradasi dan akan menghasilkan cairan (lindi) baik kuantitas maupun kualitasnya. Kuantitas dan kualitas timbulan lindi dari sampah perkotaan akan dipengaruhi oleh beberapa faktor seperti: komposisi dan karakteristik sampah, kadar air, umur sampah dan kondisi cuaca (iklim). Pada kegiatan studi ini bertujuan untuk mengetahui pengaruh komposisi sampah (jumlah fraksi organik) dan karakteristik sampah (ukuran butiran) terhadap karakteristik timbulan lindi.

Dalam rangka untuk mendapatkan tujuan studi, maka metode yang diterapkan adalah melakukan percobaan laboratorium menggunakan reaktor biodegradasi volume $1500 \mathrm{~mL}$. Dalam percobaan ini digunakan dua kelompok reaktor yaitu; kelompok pertama, digunakan untuk pengujian pengaruh persentase fraksi organik, sedangkan kelompok kedua dimaksudkan untuk pengujian pengaruh ukuran butiran sampah terhadap karakteristik lindi.

Sebagai parameter kualitas lindi ditentukan TSS, BOD, dan COD, sedangkan parameter kuantitas lindi adalah volume cairan yang keluar dari reaktor. Berdasarkan hasil percobaan diketahui bahwa jumlah (persentase) fraksi organik dan ukuran butiran sampah dapat berpengaruh terhadap karakteristik timbulan lindi. Secara keseluruhan konsentrasi TSS, $B O D$, dan COD semakin besar sejalan dengan bertambahnya persentase fraksi organik. Hal yang sama terjadi untuk ukuran butiran samaph semakin kecil, maka TSS, BOD, dan COD semakin besar. Adapun volume timbulan lindi
\end{abstract}

Kata Kunci : Sampah perkotaan, degradasi, karakteristik lindi

\section{PENDAHULUAN}

Sampah perkotaan merupakan semua jenis sampah padat yang dihasilkan dari permukiman dan kegiatan komersial. Di sebagian besar kota di Indonesia, pengelolaan sampah perkotaan dilakukan dengan membuang (menimbun) pada suatu lahan (landfill). Sejalan dengan bertambahnya waktu, maka sampah yang terdapat pada landfill akan menghasilkan cairan atau lindi. Lindi (leachate) didefinisikan sebagai cairan yang timbul akibat masuknya air eksternal ke dalam timbunan sampah, melarutkan dan membilas materi-materi terlarut, termasuk juga materi organik hasil proses biodegradasi. Timbulan lindi baik kuantitas maupun kualitas lindi akan terjadi bervariasi dan berfluktuasi Tchobanoglous, et al. (2004) akibat adanya berbagai faktor yang berpengaruh. Adapun faktor-faktor yang mempengaruhi pada kuantitas dan kualitas lindi antara lain adalah air presipitasi (hujan), evapotranspirasi, kandungan air pada sampah, tingkat kepadatan, umur sampah, temperatur, karakteristik sampah, ukuran partikel sampah dan kapasitas lapang (field capacity), (Tchobanoglous, et al. 2004) dan (Jaramillo, 2003)

Karakteristik sampah umumnya ditentukan berdasarkan adanya fraksi organik dan anorganik, dimana fraksi organik meliputi organik biodegradabel dan nonbiodegradabel. Sedangkan fraksi anorganik meliputi anatara lain: plastik, logam, kaca, tekstil dan limbah B3. Pengaruh ukuran 
butiran sampah terhadap kualitas timbulan lindi cukup signifikan. Sampah dengan distribusi butiran yang bervariasi akan mempengaruhi tingkat kerapatan yang pada gilirannya akan mempengaruhi daya kapiler air dalam tumpukan sampah. Ketidakseragaman sampah tersebut di atas menyebabkan pembentukan pori dengan berbagai ukuran, yang saling berhubungan yang akan mengalirkan air. Variasi komposisi sampah juga menyebabkan kapasitas porositas, kandungan air awal, konduktivitas hidraulik jenuh, sehingga akan berpengaruh terhadap kapasitas lapang serta pergerakan air. Hasil penelitian tentang pengaruh butiran sampah yang dilakukan dengan kolom landfill skala kecil menunjukkan bahwa berat volume sampah semakin besar sejalan dengan perubahan fase degradasi. Sama halnya untuk modulus geser juga semakin besar sejalan dengan bertambahnya umur sampah (Hossain et al., 2008). Pengaruh adanya butiran sampah juga ditunjukkan adanya perubahan konsentrasi kadar karbon ketika tahap hidrolisis yaitu karbon terkonversi sebagai asam sebanyak $68 \%$ pada sampah dengan butiran $6 \mathrm{~cm}$, sedangkan karbon terkonversi $82 \%$ untuk sampah dengan butiran $3 \mathrm{~cm}$ (Juanga, 2005).

Komposisi menentukan jenis dan kapasitas peralatan, sistem, dan program penanganannya. Komposisi sampah adalah setiap komponen sampah yang membentuk suatu kesatuan, dalam prosentase (\%). Komposisi sampah berbeda-beda berdasarkan sumber sampah, karakteristik perilaku masyarakat serta kondisi ekonomi yang berbeda dan proses penanganan sampah. Komposisi sampah perkotaan biasanya memiliki variasi bahan-bahan yang beragam baik heterogenitas dari sampah, ukuran partikel, bentuk, dan kepadatan massa sampah yang tidak merata. Komposisi sampah sangat menentukan sistem penanganan yang dapat dilakuan. Dalam rangka untuk proses penanganan sampah khususnya pengolahan secara biologi, umumnya komposisi sampah ditentukan berdasarkan tingkat biodegradasinya. Berdasarkan komposisi biodegradasinya sampah terdiri dari sampah biodegradasi cepat, sedang dan non biodegradabel. Seperti yang dilakukan oleh (Kim, et al, 2007). Dalam kegiatan ini didiskripsikan menjadi tiga fase di dalam landfill yaitu fase padat, cair dan gas. Pada fase padat mengandung dua jenis yaitu fase padat organik, fase padat anorganik, dan biomassa. Untuk fase padat organik mencakup tiga fraksi yang didasarkan pada tingkat biodegradabelnya yaitu bahan organik mudah terdegradasi, bahan organik degradasi lambat, dan bahan organik non degradable. Dari hasil penelitian diketahui bahwa Bahan organik yang terlindikan terjadi fluktuasi pada umur 1 tahun dan mulai stabil pada setelah umur 10 tahun untuk landfill Anaerobik. Sedangkan landfill aerobik terjadi lebih cepat, (Kim et al., 2007).

Studi lain tentang timbulan lindi pada sampah spesifik yaitu sampah pengolahan kayu khususnya konsentrasi logam berat juga sudah dilakukan. Dari penelitian tersebut diketahui bahwa konsentrasi 
logam berat (Chromium dan Tembaga) pada lindi pada sampah kayu lebih tinggi dibandingkan dengan sampah perkotaan (Jambeck et al., 2004).

Kualitas lindi secara umum akan dipengaruhi oleh umur sampah di landfill. Kualitas lindi akan mencapai maksimum berkisar 2 - 3 tahun setelah sampah ditempatkan pada landfill dan selanjutnya secara gradual akan menurun sampai waktu yang belum bisa ditentukan. Namun demikian tidak semua parameter kualitas lindi terjadi pada waktu yang sama, seperti BOD dan COD sampai 10 tahun konsentrasinya tinggi dan selanjutnya menurun secara gradual (FCSHWM, 1998).

Temperatur pada landfill akan mempengaruhi kualitas lindi yang dihasilkan. Sebagian besar adalah karena temperatur tidak terkendali, sehingga timbulan lindi akan berfluktuasi. Pada musim hujan dan kemarau temperature terjadi beda yang cukup mencolok. Setiap mikroorganisme memiliki suhu pertumbuhan optimal. Kelarutan garam $\mathrm{NaCl}$ akan meningkat dengan suhu. Namun, sejumlah senyawa dalam lindi, seperti $\mathrm{CaCO}_{3}$ dan $\mathrm{CaSO}_{4}$ menunjukkan penurunan kelarutan sejalan dengan meningkatnya temperature (FCSHWM, 1998). Dijelaskan bahwa konsentrasi COD terbesar pada kondisi thermofilik, disusul meshophilic dan terendah adalah psychrophilic (Wang and Pelkonen, 2008).

Lindi akan timbul secara gradual dan akan mengikuti cairan yang ada didalam sampah. Dimana kemampuan sampah menyimpan cairan antara 20 sampai $35 \%$ terhadap volume (Oweis et al., 1990). Sedangkan tingkat kandungan air serta temperatur dari sampah dalam landfill sangat berpengaruh terhadap degradasi sampah yang akhirnya akan berpengaruh terhadap lindi yang dihasilkan Wall et al, (1995). Dari sebuah studi diketahui bahwa dengan penambahan air lindi melalui resirkulasi pada sampah akan meningkatkan proses degradasi sampah, hal ini ditandai dengan konsentrasi BOD dan COD yang lebih besar untuk sampah yang diresirkulasi (Bilgili et al, 2008)

\section{METODE}

\section{Sampah Contoh}

Dalam kegiatan penelitian ini, sampah yang digunakan sebagai bahan percobaan diambil dari TPA Piyungan yang masih baru (setelah penuangan) dari truck. Dimana sampah yang baru saja dibuang dari truck sebagian dilakukan pengambilan bahan-bahan oleh para pemulung, sehingga secara karakteristik sudah berbeda dari sampah yang ada di tempat penampungan sementara (TPS). 
Setelah dilakukan karakterisasi terhadap sampah contoh, diketahui material organik biodegradabel $69,60 \%$, plastik $20,40 \%$, kertas 7,64 \%, kaca 0,93\%, kaleng 0,57\% dan tekstil 0,86\%.

\section{Set-up Percobaan}

Terdapat dua jenis reaktor yang masing-masing dijalankan dengan material sampah yang sama yaitu sampah dari TPA Piyungan. Pada jenis reaktor 1, terdiri dari 4 buah yaitu R1, R2, R3 dan R4 dengan material sampah ukuran berbeda secara berturut-turut $2,4,6$, dan $8 \mathrm{~cm}$. Sedangkan pada jenis reaktor 2 terdiri 5 buah meliputi $\mathrm{Ra}, \mathrm{Rb}, \mathrm{Rc}, \mathrm{Rd}$, dan $\mathrm{Rf}$ yang dioperasikan dengan sampah contoh fraksi organik berbeda yaitu masing-masing 58,5\%, 69,0\%, 79,3\%, 89,6\% dan $100 \%$ fraksi organik.

Untuk mengetahui karakteristik lindi, dilakukan pengambilan cairan melalui lubang yang didisain pada bagian bawah reaktor. Sebagai indikator karakteristik diuji parameter Total Disolved Solid (TDS), Biochemical Oxygen Demand (BOD) dan Chemical Oxygen Demand (COD). COD merupakan salah satu parameter yang dipakai sebagai indikator adanya bahaya lindi terhadap pencemaran air tanah dan kontaminasi pada lahan (Tchobanoglous et al.,2004). Adapun metode yang digunakan untuk pengujian masing-masing paramater tersebut adalah SNI 06-6989.3-2004 untuk parameter TDS sedangkan SNI 06-6989.15-2004 untuk BOD dan COD

\section{HASIL DAN PEMBAHASAN}

Pada studi ini, sebagai indikator kualitas timbulan lindi adalah adanya bahan organik terlarut antara lain: Total Disolved Solid (TDS) atau material padatan terlarut, Biochemical Oxygen Demand (BOD), dan Chemical Oxygen Demand (COD). Setelah dilakukan pengujian terhadap parameter tersebut pada berbagai umur sampah dalam reaktor biodegradasi diperoleh hasil-hasil sebagai berikut:

\subsection{TDS}

Total disolved solid (TDS) merupakan salah satu parameter kualitas lindi yang perlu diketahui konsentrasinya, hal ini digunakan sebagai dasar untuk mendesain sistem pengolahan tahap penanganan berikutnya seperti Instalasi Pengolahan Lindi (IPL). Pengujian TDS pada umur degradasi 21, 25, dan 50 hari untuk ukuran partikel sampah serta komposisi fraksi organik berbeda seperti dijelaskan pada Tabel 1 dan Gambar 1. 
Tabel 1. Konsentrasi TDS Lindi Berbagai Ukuran Partikel dan Persentase Fraksi Organik

\begin{tabular}{|l|c|c|c|}
\hline \multirow{2}{*}{$\begin{array}{c}\text { Ukuran Partikel } \\
\text { dan Persentase }\end{array}$} & \multicolumn{3}{|c|}{ TDS (mg/L) } \\
\cline { 2 - 4 } Fraksi Organik & $\mathbf{2 1 ~ h a r i}$ & $\mathbf{3 5}$ hari & $\mathbf{5 0}$ hari \\
\hline Ukuran partikel sampah (cm) & \multicolumn{2}{|c|}{} \\
\hline $8 \mathrm{~cm}$ & 564 & 750 & 623 \\
\hline $6 \mathrm{~cm}$ & 869 & 880 & 880 \\
\hline $4 \mathrm{~cm}$ & 697 & 805 & 738 \\
\hline $2 \mathrm{~cm}$ & 1232 & 1250 & 1412 \\
\hline Fraksi organik $(\%)$ & 541 & 799 & 633 \\
\hline $58,5 \%$ & 549 & 1300 & 692 \\
\hline $69,0 \%$ & 659 & 1400 & 1012 \\
\hline $79,3 \%$ & 670 & 1465 & 1035 \\
\hline $89,6 \%$ & 723 & 1810 & 1063 \\
\hline $100 \%$ & & & \\
\hline
\end{tabular}
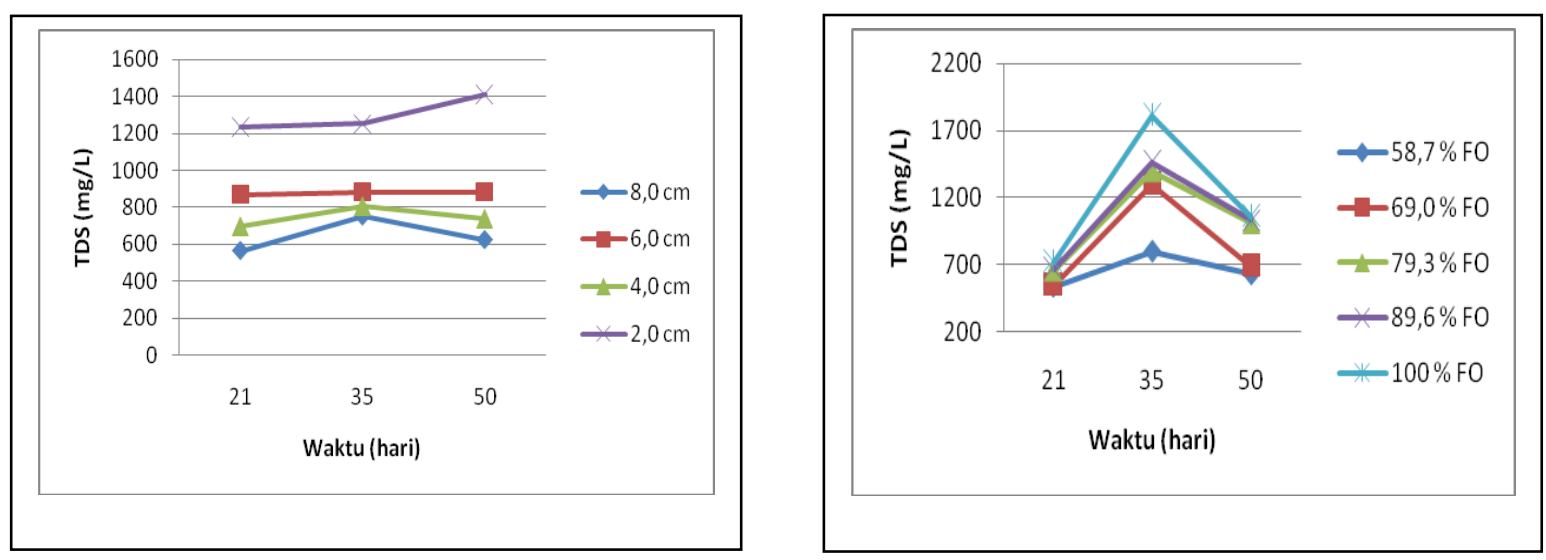

Gambar 1. Konsentrasi TDS Lindi Pada Ukuran Partikel dan Persentase Fraksi Organik

Dari Tabel 1 dan Gambar 1 tersebut di atas diketahui bahwa konsentrasi TDS semakin besar sejalan dengan semakin kecil ukuran partikel sampah. Hasil yang sama juga terjadi pada komposisi fraksi organik yaitu semakin besar fraksi organik TDS semakin besar. Didasarkan pada waktu degradasi, diketahui bahwa terjadi perubahan yang cukup signifikan khususnya untuk fraksi organik, yaitu pada pengujian 35 hari TDS menunjukkan yang terbesar. Sedangkan untuk ukuran partikel tidak memberikan perubahan TDS yang besar. Diketahui bahwa ukuran butiran lebih besar dari $4 \mathrm{~cm}$ menunjukkan perubahan TDS yang tidak signifikan, adapun persentase fraksi oragnik tidak memberikan perubahan yang cukup siginifikan, kecuali pada 58,7\% dan $100 \%$ fraksi organik dengan waktu operasi reaktor 35 hari. 
TDS dalam lindi dapat berasal dari padatan berupa sampah maupun butiran-butiran kecil yang melekat pada sampah. Melalui proses fisik, kimia dan biologi padatan tersebut akan terlepas dari sampah yang selanjutnya terlarut dalam lindi. Ukuran partikel sampah yang kecil menjadikan luas permukaan yang lebih besar, sehingga akan meningkatkan proses pelarutan dan degradasi. Dalam sampah perkotaan yang terjadi degradasi adalah material organik, oleh karena itu dengan semakin besarnya komposisi fraksi organik maka TDS menjadi lebih besar.

\subsection{BOD}

Hasil pengujian Biochemical Oxygen Demand (BOD) pada umur degradasi 21, 35 dan 50 hari pada sampah ukuran partikel 2, 4, 6, $8 \mathrm{~cm}$ dan komposisi 58,7 \%, $69 \%, 79,3 \%, 89,6 \%$ dan 100\% fraksi organik ditunjukkan pada Tabel 2 dan Gambar 2. Diketahui bahwa ukuran partikel lebih kecil, nilai BOD semakin besar dan menurun seiring dengan bertambahnya waktu degradasi. Seperti halnya TDS, untuk BOD juga lebih besar seiring dengan besarnya komposisi fraksi organik dalam sampah. BOD merupakan indikator adanya proses biodegradasi sampah, oleh karena itu adanya BOD yang tinggi menunjukkan bahwa sedang terjadi proses degradasi lebih cepat. Sedangkan pada ukuran partikel yang kecil maka menjadikan proses degradasi lebih cepat khususnya pada fase hidrolisis menunjukkan bahwa luas permukaan berpengaruh terhadap kecepatan degradasi sampah. Adapun meningkatnya BOD dengan bertambahnya komposisi organik disebabkan adanya material degradabel pada sampah yang semakin besar.

Tabel 2. Konsentrasi BOD Lindi Pada Berbagai Ukuran Partikel dan Persentase Fraksi Organik

\begin{tabular}{|c|c|c|c|}
\hline & \multicolumn{3}{|c|}{ BOD (mg/L) } \\
\hline Ukuran partikel sampah (cm) & $\mathbf{2 1}$ hari & $\mathbf{3 5}$ hari & $\mathbf{5 0}$ hari \\
\hline $8 \mathrm{~cm}$ & 660 & 637 & 620 \\
\hline $6 \mathrm{~cm}$ & 671 & 652 & 640 \\
\hline $4 \mathrm{~cm}$ & 751 & 694 & 660 \\
\hline $2 \mathrm{~cm}$ & 790 & 720 & 676 \\
\hline Fraksi organik (\%) & & & \\
\hline $58,5 \%$ & 515 & 319 & 360 \\
\hline $69,0 \%$ & 565 & 472 & 527 \\
\hline $79,3 \%$ & 597 & 568 & 674 \\
\hline $89,6 \%$ & 652 & 565 & 681 \\
\hline $100 \%$ & 680 & 637 & 662 \\
\hline
\end{tabular}



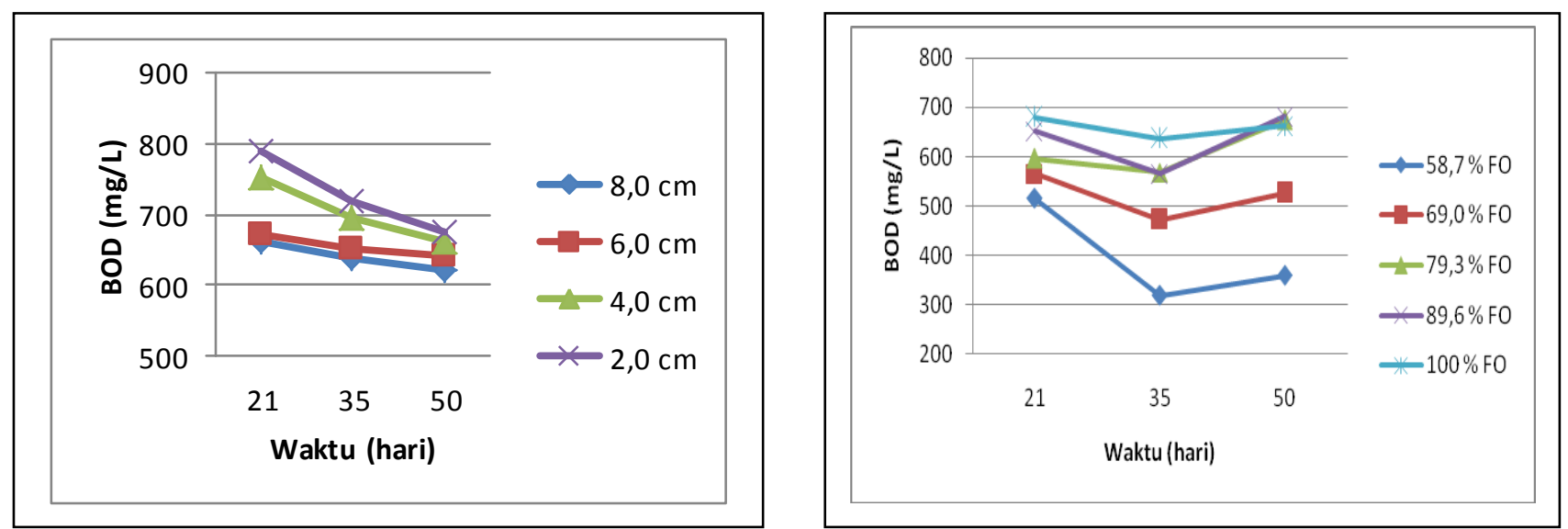

Gambar 2. Konsentrasi BOD Lindi Pada Berbagai Ukuran Partikel dan Persentase Fraksi Organik

\subsection{COD}

Hasil pengujian terhadap COD lindi untuk masing-masing sampel ditunjukkan pada Tabel 3 dan Gambar 3. Diketahui bahwa konsentrasi COD pada lindi terjadi variasi baik pada ukuran partikel yang berbeda, komposisi fraksi organik maupun pada waktu degradasi.

Tabel 3. Konsentrasi COD dan Rasio BOD/COD Lindi Pada

Berbagai Ukuran Partikel dan Persentase Fraksi Organik

\begin{tabular}{|l|r|r|r|r|r|r|}
\hline \multirow{2}{*}{$\begin{array}{c}\text { Ukuran Partikel } \\
\text { dan Persentase } \\
\text { Fraksi Organik }\end{array}$} & \multicolumn{3}{|c|}{ COD (mg/L) } & \multicolumn{3}{c|}{ Rasio BOD/COD } \\
\cline { 2 - 7 } & $\mathbf{2 1}$ hari & $\mathbf{3 5}$ hari & $\mathbf{5 0}$ hari & $\mathbf{2 1}$ hari & $\mathbf{3 5}$ hari & $\mathbf{5 0}$ hari \\
\hline Ukuran partikel sampah (cm) & 1150 & 1150 & 1225 & 0,57 & 0,52 & 0,53 \\
\hline $8 \mathrm{~cm}$ & 1300 & 1300 & 1360 & 0,52 & 0,48 & 0,48 \\
\hline $6 \mathrm{~cm}$ & 1623 & 1623 & 1720 & 0,46 & 0,40 & 0,38 \\
\hline $4 \mathrm{~cm}$ & 1650 & 1650 & 1750 & 0,48 & 0,41 & 0,38 \\
\hline $2 \mathrm{~cm}$ & 1555 & 1555 & 1575 & 0,33 & 0,20 & 0,22 \\
\hline Fraksi organik (\%) & 1525 & 1525 & 1560 & 0,37 & 0,30 & 0,32 \\
\hline $58,5 \%$ & 1475 & 1475 & 1490 & 0,40 & 0,38 & 0,39 \\
\hline $69,0 \%$ & 1555 & 1555 & 1575 & 0,42 & 0,36 & 0,42 \\
\hline $79,3 \%$ & 1525 & 1525 & 1560 & 0,45 & 0,41 & 0,40 \\
\hline $89,6 \%$ &
\end{tabular}

Ukuran partikel sampah semakin kecil maka COD semakin besar masing-masing 790, 751, 671, dan $660 \mathrm{mg} / \mathrm{L}$ berturut-turut untuk ukuran partikel 2, 4, 6, dan $8 \mathrm{~cm}$. Sama halnya pada persentase fraksi organik, diketahui COD semakin besar seiring dengan meningkatnya persentase fraksi 
organik. Pada awal pengoperasian alat percobaan, rasio BOD/COD sekitar 0,45 hari ke 21 selanjutnya mulai berkurang pada hari ke 35 dan 50, seperti yang ditunjukkan pada Tabel 3. Hal ini menunjukkan bahwa pada proses degradasi sampai hari ke 50 masih dalam fase hidrolisis. Nilai ini sesuai dengan hasil penelitian sebelumnya yang menyatakan bahwa pada tahap awal untuk sampah muda rasio BOD/COD lebih besar dan mulai menurun setelah memasuki fase berikutnya (Bilgili $e t$ al., 2006).
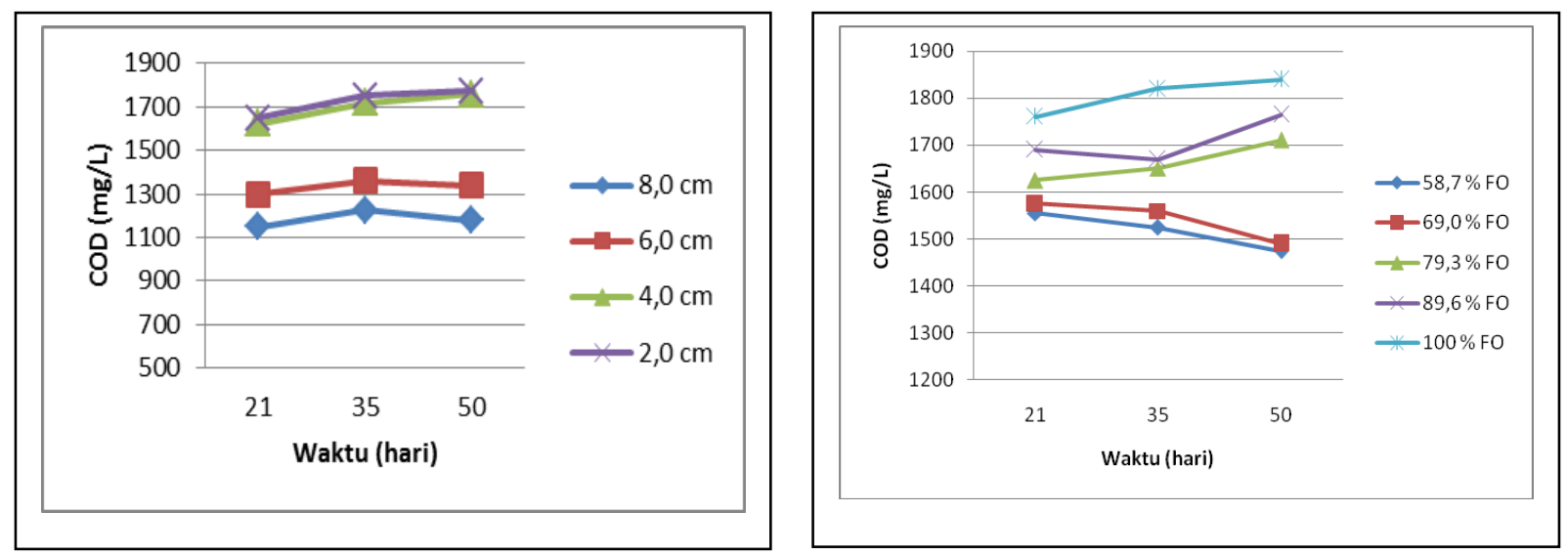

Gambar 3. Konsentrasi COD Lindi Pada Berbagai Ukuran Partikel dan Persentase Fraksi Organik

\subsection{Volume Timbulan Lindi}

Tabel 4. Volume Timbulan Lindi Pada Berbagai Ukuran partikel dan Fraksi Organik

\begin{tabular}{|c|c|c|c|}
\hline & \multicolumn{3}{|c|}{ Volume Lindi (ml) } \\
\hline $\begin{array}{c}\text { Ukuran partikel } \\
\text { sampah (cm) }\end{array}$ & $\mathbf{2 1}$ hari & $\mathbf{3 5}$ hari & $\mathbf{5 0}$ hari \\
\hline $8 \mathrm{~cm}$ & 53,33 & 42,50 & 35,40 \\
\hline $6 \mathrm{~cm}$ & 50,00 & 40,00 & 31,00 \\
\hline $4 \mathrm{~cm}$ & 36,67 & 30,20 & 26,10 \\
\hline $2 \mathrm{~cm}$ & 33,33 & 28,30 & 24,00 \\
\hline \multicolumn{3}{|c|}{} \\
\hline Fraksi organik (\%) & 70,00 & 58,40 & 40,20 \\
\hline $58,5 \%$ & 56,67 & 41,50 & 26,70 \\
\hline $69,0 \%$ & 50,00 & 39,50 & 22,30 \\
\hline $79,3 \%$ & 50,00 & 38,60 & 21,50 \\
\hline $89,6 \%$ & 36,67 & 30,00 & 18,30 \\
\hline $100 \%$ &
\end{tabular}

Dari hasil pengukuran setelah reaktor berjalan 21, 35 dan 35 hari diketahui volume cairan (lindi) yang keluar pada bagian bawah reaktor seperti ditunjukkan pada tabel 4. Diketahui bahwa, semakin kecil ukuran partikel volume lindi semakin kecil. Sedangkan untuk fraksi 
organik semakin sedikit menghasilkan volume semakin kecil. Hal ini menunjukkan bahwa dalam proses degradasi material organik memerlukan air baik untuk reaksi maupun terabsorb oleh material sampah.

\section{1. Kesimpulan}

Berdasarkan serangkaian percobaan, analisis dan pembahasan terhadap karakteristik sampah dan karakteristik lindi dapat disimpulkan bahwa:

a. Ukuran butiran sampah dan komposisi fraksi organik dalam sampah akan berpengaruh terhadap kuantitas dan kualitas lindi.

1) Butiran sampah dengan ukuran lebih dari $4 \mathrm{~cm}$ tidak berpengaruh besar terhadap perubahan parameter TDS. Sedangkan untuk persentase fraksi organik memberikan perubahan TDS tidak besar.

2) Parameter BOD dan COD akan terjadi perubahan secara liniear sejalan dengan berubahnya ukuran butiran dan persentase fraksi organik.

b. Volume timbulan lindi semakin menurun secara liniear sejalan dengan ukuran partikel semakin kecil dan meningkatnya persentase organik.

\subsection{Saran}

Proses degradasi sampah akan terjadi dengan waktu yang lama, sehingga diperlukan pengambilan sampel untuk pengujian parameter TDS, BOD, dan COD dengan durasi yang lebih lama.

\section{DAFTAR PUSTAKA}

Bilgili. M.S, Ahmet demir., Bestamin Ozkaya., (2008), Quality and Quantity of Leachate in Aerobic Pilot-Scale Landfills., Environmental Management Vol. 38, No. 2, pp. 189-196, 2008.

Florida Center for Solid and Hazardous Waste Management (FCSHWM), (1998), Analysis of Florida MSW landfill leachate quality. University of Central Florida, Florida. (1998).

Hossain. M.S, Pennethsa K.K, Hoyos L, (2009), Permeability of Municipal Solid Waste in Bioreaktor Landfill with Degradation, Geitech Geol Eng (2009), 27: 43-51

Jaramillo. J, (2003), Guidelines for the Design, Construction and Operation of Manual Sanitary Landfills, Universidad de Antioquia, Colombia. 
Juanga. J.P, (2005), Optimizing Dry Anaerobic Digestion of Organik Fraction of Municipal Solid Waste, A thesis of Master of Engineering, Asian Institute of Technology, School of Environment, Resources and Development Thailand, 2005.

Oweis, Issa S., Smith, Donald A., Ellwood, R. Brian, and Greene, Daniel, (1990), "Hydraulic Characteristic of Municipal Refuse," Journal of Geotechnical Engineering, Vol. 116, No.4, April, 1990.

Kim. S.Y, Tojo. Y, Matsuto. T, (2007), Compartment model of aerobic and anaerobic biodegradation in a municipal solid waste landfill, Waste Management \& Research, 2007,: 25: 524-537.

Tchobanoglous G, Theisen. H, and Vigil. S. A., (2004) Integrated Solid Waste Management, Engineering Principles and Management Issues, McGraw-Hill, New York

Wang. Y and Pelkonen. M.,(2008), Inpacts of Temperature and Liquid/Solid Ratio on Anaerobic Degradation of Municipal Solid Waste: An Emission Investigation of Landfill Simulation Reaktors, Special Feature on APLAS Saporo, 2008

Wall and Zeis Chris, (1995), "Municipal Landfill Biodegradation and Settlement," Journal of Environmental Engineering, Vol. 121, No. 3, pp. 214-223, 1995. 